\title{
THE EFFECTS OF CROSSING BALKAN AND SAANEN GOAT BREEDS ON CARCASS TRAITS AND CERTAIN QUALITY PARAMETERS OF KID MEAT*
}

\author{
Nikola Stanišić ${ }^{1}$, Miroslav Žujović ${ }^{2}$, Zorica Tomić ${ }^{3}$, \\ Nevena Maksimović ${ }^{2}$, Zorica Bijelić ${ }^{3}$, Snežana Ivanović ${ }^{4}$, \\ Nurgin Memiši ${ }^{5}$
}

${ }^{1}$ Department of Meat Science and Technology, ${ }^{2}$ Department of Animal Breeding and Reproduction, ${ }^{3}$ Department of Ecology and Animal Food Production, Institute for Animal Husbandry, Auto put 16, 11080 Belgrade-Zemun, Serbia ${ }^{4}$ Scientific Institute of Veterinary Medicine, Vojvode Toze 14, 11000 Belgrade, Serbia ${ }^{5}$ AD Mlekara - Subotica, Tolminska 10, 24000 Subotica, Serbia

\begin{abstract}
The possibility for improvement of carcass traits and quality of kid meat of the autochthonous Balkan goat breed by crossing with Saanen breed was investigated in this study. The trial was carried out on one group of Balkan goat kids and three groups of kid crosses of Balkan and Saanen goats with different proportion of Saanen genes: 25,50 and $75 \%$. Each group had 16 male kids, which were slaughtered at the average body weight of $18 \mathrm{~kg}$. With the increase in the proportion of Saanen genes, the age of kids that reached preslaughter weight decreased, the chilling loss increased and the proportion of fat tissue (kidney and pelvic fat) in the carcass side decreased $(P \leq \mathbf{0 . 0 5})$. The crossing also increased the proportion of carcass parts of the first category (leg and loin section), as well as muscle tissue in those parts. The highest proportion of muscle tissue in the thigh $(\mathbf{7 4 . 9 1 \% )}$ ) and loin section $(\mathbf{7 5 . 6 6 \%})$ was determined in kids from the group with $\mathbf{7 5 \%}$ of Saanen genes, and kids from this group also had the highest proportion of intramuscular fat $(\mathbf{2 . 4 8 \%})$ in samples of $\boldsymbol{m}$. longissimus dorsi. Slight differences between kid groups were established in indicators of technological meat properties, such as water binding capacity and tenderness, with the increase in the proportion of Saanen genes in the genotype. Sensory score for roasted meat was high, and scores for tenderness and juiciness were slightly higher in kid crosses with $\mathbf{5 0 \%}$ and $75 \%$ of Saanen genes $(\mathrm{P} \leq \mathbf{0 . 0 5})$. Results presented in this study confirm the positive effect of crossing the Saanen breed with the Balkan breed on carcass traits and for obtaining meat of more desirable quality.
\end{abstract}

Key words: kid, genotype, carcass traits, proportion of tissues, meat quality

Since 1985, there has been a significant increase in goat numbers all over the world. The increasing interest in goat meat is due to the fact that goats have a very low amount of subcutaneous fat tissue and intramuscular fat, which is why they

\footnotetext{
* Research was financed by the Ministry of Education and Science, Republic of Serbia, project no. TR-31053.
} 
produce carcasses that are very lean, compared with sheep of similar ages (ColomerRocher et al., 1992). However, unlike cattle and sheep, due to low economic significance in the developed countries, there is very little information in the scientific literature pertaining to carcass composition and quality of meat of autochthonous goat breeds (Tshabalala et al., 2003). Regarding this, there is little published information relating to the potential of increased weight at slaughter in dairy goat kids to maximize meat production.

A significant part of the goat population in the hilly mountainous area of Serbia is formed by the domestic Balkan goat breed from red to fritillary colour, with varieties of black, white and spotted colour. It is a dairy goat breed, with typically more developed front part of the body compared to the rear, of a rougher constitution, very resistant to diseases and undemanding in terms of nutrition and care. The goat population is mostly located in smallholder farming areas and the traditional production system is extensive.

Although the number of goats in Serbia has been constantly increasing in recent years (Žujović et al., 2009), because the consumption of goat meat is not part of tradition, it cannot easily be found in retail shops and it is mainly purchased directly from breeders. Goats are reared primarily for production of milk, and male kids, because of poor carcass conformation, are usually excluded from rearing. A solution to this problem is improvement of carcass conformation and quality of meat obtained from male kids. One of the ways to realize this is by crossing autochthonous breeds with pure breeds. Beetal, Boer, Jamunapari and Nubian goat breeds, which are characterized by fast growth and large size, and dairy goat breeds such as Alpine and Saanen are most often used for crossing to improve meat traits and yield of the carcass (Devendra, 1982; Glimp, 1995; Wen et al., 1997).

In Serbia, noble goat breeds that are mainly present are Saanen, followed by Alpine and most recently German Spotted and Fawn breeds. However, the Saanen breed, as a dairy goat breed, is mostly used for crossing for the purpose of improving the domestic autochthonous goat breed. Therefore, the objective of the present study was to evaluate the effect of crossing the Balkan autochthonous goat breed with various proportions of Saanen genes, on carcass and meat quality parameters. The focus was on analysis of the carcass traits and composition, as well as chemical and technological meat properties. Data obtained in this study will complement our rather modest knowledge of possibilities for crossing autochthonous breeds with pure and noble breeds, and can also be a basis for organized breeding-selection work.

\section{Material and methods}

The trial was carried out in the Institute for Animal Husbandry (Belgrade, Serbia), on one group of kids of the Balkan breed (B) and three groups of its crosses with Saanen goats. Crosses had different proportions of Saanen genes: $25 \%(3 / 4 \mathrm{~B} 1 / 4 \mathrm{~S})$, $50 \%\left(1 / 2 \mathrm{~B}^{1} / 2 \mathrm{~S}\right)$ and $75 \%\left(1 / 4 \mathrm{~B}^{3} / 4 \mathrm{~S}\right)$. Each of four groups consisted of 16 male kids (all kids were born as twins). After weaning at 90 days of age, kids were reared under 
an intensive system of management and fed with grass hay and concentrate. Hay consisted of grass mixture (Festucetum vallesiacae association) which comprises 57 species of uniform quality with regard to content of crude protein (7.60-9.53\%) and crude fibre (27.49-29.55\%). Composition of the concentrate used in the feeding was as follows: proteins $(16.0 \%)$, moisture $(13.5 \%)$, fibre $(8.0 \%)$, ash $(8.0 \%)$, calcium $(0.8-1.0 \%)$, phosphorus $(0.5-0.7 \%)$ and sodium $(0.2-0.3 \%)$, with an addition of vitamins and minerals. Feeding was ad libitum and in groups until slaughter.

After reaching $18 \mathrm{~kg}$ of body weight, all animals were transported to the slaughterhouse. They were denied feed $12 \mathrm{~h}$ prior to slaughtering, but they had free access to water. Animals were weighed before slaughtering (slaughter live weight - SLW), and then the kids were electrically stunned and slaughtered according to standard commercial procedures. After the removal of skin and head, front and rear legs and evisceration, carcasses were placed in cold storage at $4^{\circ} \mathrm{C}$ for the next 24 hours. One hour after slaughtering and primary processing of the carcass the weights of hot carcass (HCW), offal (heart, lungs, liver, kidneys, spleen, rumen, abomasum, small and large intestines), skin, head and legs, were recorded. Empty body weight (EBW) was calculated by deducting the weight of digesta. Subsequent to cooling the weight of cold carcass $(\mathrm{CCW})$ and weight of fat tissue in the carcass (pelvic and kidney fat) were determined and the dressing percentage and chilling loss were calculated.

After chilling, the carcasses were split along the vertebral column into two halves, and the left side was used for all measurements. The left side of each carcass was divided into seven anatomical regions: leg, loin section, shoulder, neck, back, chest with fore thigh and second thigh, using a standard technique. Thigh, loin, shoulder and back were separated into dissectible fat (subcutaneous and intramuscular), muscle and bone tissue. The thickness of subcutaneous fat tissue ( $\mathrm{mm}$ ) was measured with a caliper on the back at cross-section between the 12th and 13th rib and on chest in the area between the 3rd and 4th rib.

After dissection, the weight and length of $m$. longissumus dorsi was recorded. The cross-section of the 13th rib for maximum width (A: distance from the medial border to the lateral extremity of longissimus) and depth (B: distance perpendicular to the width) of the longissimus were measured with a caliper and rib eye area was calculated as $((\mathrm{A} / 2) \times(\mathrm{B} / 2) \times \pi)$.

Samples of the longissimus dorsi muscle from the loin were taken from cooled carcasses. Water binding capacity was determined according to the method of Grau et al. (1953) and $\mathrm{pH}$ value of meat was measured by insertion of $\mathrm{pH}$ meter with combined electrode HI 83141 (Hanna Instruments, USA) using a muscle sample collected 24 hours postmortem. All samples were analysed for basic chemical composition: quantity of water, quantity of intramuscular fat, amount of protein and amount of mineral substances (ash) (AOAC, 1990). The quantity of collagen in muscle samples was determined spectrophotometrically by determining the content of hydroxyproline and multiplying it by a factor of 7.25. The content of total pigments was determined according to the method of Horsney (Bunning and Hamm, 1970).

The loss of weight during cooking (cooking loss) in muscle samples was determined based on difference in weight of one piece of meat $(3 \times 4 \times 1.5 \mathrm{~cm})$ before and after cooking $\left(100^{\circ} \mathrm{C} / 10 \mathrm{~min}\right)$ and expressed in percentage. Muscle samples used 
for determination of cooking loss were cut into $1 \times 1 \mathrm{~cm}$ pieces in the direction of muscle fibres. Tenderness of meat, expressed as shear force, was measured on the Warner-Bratzler apparatus. Higher recorded values represented higher shear force, i.e. tougher meat.

Sensory analysis was done by seven semi-trained evaluators on samples of $m$. longissimus dorsi $(5 \times 3 \times 2 \mathrm{~cm})$ after roasting at $180-190^{\circ} \mathrm{C} / 10 \mathrm{~min}$. In sensory evaluation, the 5-point system was used: from 1 (extremely unacceptable) to 5 (extremely acceptable). The following attributes of roasted meat were scored: smell, taste/flavour, tenderness and juiciness.

In order to determine the effect of breed on carcass, meat quality and sensory characteristics of roasted meat, a single-factor analysis of variance was performed using Statistica 7 software (StatSoft, USA). If the effect of breed was found significant, Tukey's test was used to evaluate the significance of difference.

\section{Results}

Carcass traits, thickness of subcutaneous fat tissue, and proportions of fat depot, offal, skin, head and legs are presented in Table 1. On average, crosses with 25, 50 and $75 \%$ of the Saanen genes reached the preslaughter weight 3, 10 and 16 days earlier, respectively, than Balkan kids $(\mathrm{P} \leq 0.05)$. The proportion of lungs, liver and small intestine increased with the proportion of Saanen genes $(\mathrm{P} \leq 0.05)$. Statistically significant differences between kid genotypes were also established for chilling loss, thickness of the subcutaneous fat tissue and proportion of kidney fat tissue.

The proportion of main kid carcass parts varied significantly depending on the genotype (Table 2). The proportion of leg and neck was the highest in kid crosses with $75 \%$ of Saanen genes and the lowest in purebred Balkan kids. Kids of the $1 / 4 \mathrm{~B}^{3} / 4 \mathrm{~S}$ group had the highest proportion of parts of the first category (leg + loin).

Results of the dissection of leg, loin, shoulder and back are presented in Table 3 . The proportion of muscle tissue in the leg and loin was significantly higher in kid crosses, whereas the proportion of bones in these two carcass parts decreased with the increase in the proportion of Saanen genes in the genotype $(\mathrm{P} \leq 0.05)$. A statistically significant difference was established for the proportion of fat tissue obtained by dissection of shoulder and back.

Table 4 presents the traits, chemical composition and technological properties of samples of longissimus dorsi muscle. A statistically significant difference $(\mathrm{P} \leq 0.05)$ was established for muscle weight and cross-section surface between kids. The crossing of Balkan and Saanen breeds also influenced a significant increase in the proportion of intramuscular fat $(\mathrm{P} \leq 0.05)$. Genotype had an impact on the water binding capacity which was the highest (the lowest amount of released meat juice) in meat of kids in group B $\left(7.12 \mathrm{~cm}^{2}\right)$. The meat of this group of kids was the tenderest, i.e. it had the lowest shear force values.

Table 5 presents data pertaining to sensory evaluation of samples of longissimus dorsi muscle after roasting. The meat of kids with 50 and $75 \%$ of Saanen genes received the highest score for tenderness and juiciness $(\mathrm{P} \leq 0.05)$. 
Table 1. Age, carcass traits and proportion of offals, skin, head and legs of kids of different genotypes

\begin{tabular}{|c|c|c|c|c|c|}
\hline Parameters & $\mathrm{B}$ & $3 / 4 \mathrm{~B} 1 / 4 \mathrm{~S}$ & $1 / 2 \mathrm{~B} 1 / 2 \mathrm{~S}$ & $1 / 4 \mathrm{~B} 3 / 4 \mathrm{~S}$ & t-test \\
\hline \multicolumn{6}{|l|}{ Carcass traits } \\
\hline SLW (kg) & $18.48 \pm 0.47$ & $18.32 \pm 0.62$ & $18.35 \pm 0.34$ & $18.68 \pm 0.53$ & ns \\
\hline EBW (kg) & $14.38 \pm 0.42$ & $14.23 \pm 0.51$ & $14.43 \pm 0.30$ & $14.77 \pm 0.35$ & ns \\
\hline $\mathrm{HCW}(\mathrm{kg})$ & $7.98 \pm 0.23$ & $7.87 \pm 0.21$ & $7.99 \pm 0.17$ & $8.04 \pm 0.27$ & ns \\
\hline CCW (kg) & $7.64 \pm 0.19$ & $7.55 \pm 0.23$ & $7.59 \pm 0.28$ & $7.60 \pm 0.18$ & ns \\
\hline HCW/SLW (\%) & $43.16 \pm 1.10$ & $42.95 \pm 0.88$ & $43.50 \pm 1.03$ & $42.99 \pm 1.24$ & ns \\
\hline $\mathrm{HCW} / \mathrm{EBW}(\%)$ & $55.46 \pm 1.56$ & $55.28 \pm 1.49$ & $55.36 \pm 1.12$ & $54.41 \pm 2.02$ & ns \\
\hline CCW/SLW (\%) & $41.31 \pm 0.79$ & $41.23 \pm 1.24$ & $41.38 \pm 1.16$ & $40.70 \pm 0.81$ & ns \\
\hline CCW/EBW (\%) & $53.12 \pm 1.14$ & $52.98 \pm 0.78$ & $52.58 \pm 1.22$ & $51.47 \pm 1.32$ & ns \\
\hline chilling loss (\%) & $4.26 \mathrm{a} \pm 0.07$ & $4.10 \mathrm{a} \pm 0.09$ & $5.00 \mathrm{~b} \pm 0.10$ & $5.46 \mathrm{c} \pm 0.11$ & $*$ \\
\hline \multicolumn{6}{|c|}{ Thickness of fat tissue } \\
\hline on chest (mm) & $6.25 \mathrm{~b} \pm 0.15$ & $6.32 \mathrm{~b} \pm 0.15$ & $5.50 \mathrm{a} \pm 0.12$ & $5.83 \mathrm{a} \pm 0.13$ & $*$ \\
\hline on back (mm) & $3.71 \mathrm{c} \pm 0.11$ & $3.12 \mathrm{ab} \pm 0.08$ & $3.31 b \pm 0.08$ & $2.87 \mathrm{a} \pm 0.07$ & $*$ \\
\hline \multicolumn{6}{|c|}{ Depot fat (\% of EBW) } \\
\hline pelvic & $0.54 \pm 0.03$ & $0.52 \pm 0.02$ & $0.47 \pm 0.03$ & $0.43 \pm 0.02$ & ns \\
\hline kidney & $0.73 b \pm 0.01$ & $0.65 \mathrm{~b} \pm 0.02$ & $0.49 \mathrm{a} \pm 0.02$ & $0.46 \mathrm{a} \pm 0.01$ & $*$ \\
\hline total & $1.43 b \pm 0.04$ & $1.39 \mathrm{~b} \pm 0.04$ & $1.10 \mathrm{a} \pm 0.03$ & $1.06 \mathrm{a} \pm 0.03$ & $*$ \\
\hline \multicolumn{6}{|l|}{ Offal (\% of EBW) } \\
\hline large intestine & $2.25 \pm 0.09$ & $2.30 \pm 0.08$ & $2.13 \pm 0.08$ & $1.99 \pm 0.06$ & ns \\
\hline rumen & $3.06 \pm 0.06$ & $2.79 \pm 0.07$ & $3.08 \pm 0.08$ & $2.98 \pm 0.06$ & ns \\
\hline small intestine & $3.21 \mathrm{a} \pm 0.06$ & $3.42 \mathrm{ab} \pm 0.05$ & $3.79 b \pm 0.08$ & $3.83 \mathrm{~b} \pm 0.08$ & $*$ \\
\hline abomasum & $0.72 \pm 0.03$ & $0.78 \pm 0.03$ & $0.78 \pm 0.02$ & $0.75 \pm 0.03$ & ns \\
\hline liver & $2.68 \mathrm{a} \pm 0.06$ & $2.81 \mathrm{a} \pm 0.07$ & $3.03 \mathrm{~b} \pm 0.05$ & $3.19 \mathrm{~b} \pm 0.08$ & $*$ \\
\hline lungs & $1.90 \mathrm{a} \pm 0.03$ & $2.12 \mathrm{ab} \pm 0.03$ & $2.21 \mathrm{~b} \pm 0.04$ & $2.29 \mathrm{~b} \pm 0.05$ & $*$ \\
\hline heart & $0.50 \pm 0.02$ & $0.54 \pm 0.01$ & $0.57 \pm 0.01$ & $0.63 \pm 0.02$ & ns \\
\hline spleen & $0.26 \pm 0.01$ & $0.29 \pm 0.01$ & $0.31 \pm 0.01$ & $0.28 \pm 0.02$ & ns \\
\hline kidneys & $0.53 \pm 0.02$ & $0.56 \pm 0.02$ & $0.53 \pm 0.01$ & $0.55 \pm 0.01$ & ns \\
\hline Skin $(\%$ of EBW) & $10.10 \pm 0.42$ & $9.76 \pm 0.26$ & $9.84 \pm 0.38$ & $9.71 \pm 0.44$ & ns \\
\hline Head ( $\%$ of EBW) & $5.58 \pm 0.14$ & $5.66 \pm 0.15$ & $5.63 \pm 0.20$ & $5.55 \pm 0.11$ & ns \\
\hline Legs $(\%$ of EBW) & $3.93 \pm 0.10$ & $3.88 \pm 0.12$ & $3.97 \pm 0.08$ & $3.95 \pm 0.16$ & $\mathrm{~ns}$ \\
\hline
\end{tabular}

Results are expressed as arithmetic mean and standard deviation.

$\mathrm{a}, \mathrm{b}, \mathrm{c}, \mathrm{d}-$ means within rows bearing different letters are significantly different at $\mathrm{P} \leq 0.05$.

$* \mathrm{P} \leq 0.05$.

ns - non-significant.

Table 2. Left side weight and the proportion of main carcass side parts in different kid genotypes

\begin{tabular}{l|r|r|r|r|c}
\hline \multicolumn{1}{c|}{ Parameters } & \multicolumn{1}{c|}{$\mathrm{B}$} & \multicolumn{1}{c|}{$3 / 4 \mathrm{~B} 1 / 4 \mathrm{~S}$} & \multicolumn{1}{c|}{$1 / 2 \mathrm{~B} 1 / 2 \mathrm{~S}$} & \multicolumn{1}{c}{$1 / 4 \mathrm{~B} 3 / 4 \mathrm{~S}$} & $\mathrm{t}$-test \\
\hline Left side weight (kg) & $3.79 \pm 0.08$ & $3.73 \pm 0.09$ & $3.77 \pm 0.06$ & $3.76 \pm 0.09$ & $\mathrm{~ns}$ \\
Leg (\%) & $24.11 \mathrm{a} \pm 0.50$ & $24.76 \mathrm{a} \pm 0.52$ & $26.23 \mathrm{~b} \pm 0.39$ & $27.08 \mathrm{~b} \pm 0.44$ & $*$ \\
Loin (\%) & $10.85 \pm 0.22$ & $10.92 \pm 0.31$ & $11.00 \pm 0.17$ & $10.90 \pm 0.36$ & $\mathrm{~ns}$ \\
Shoulder (\%) & $20.45 \pm 0.47$ & $20.52 \pm 0.53$ & $20.50 \pm 0.35$ & $20.32 \pm 0.33$ & $\mathrm{~ns}$ \\
Back (\%) & $8.42 \mathrm{c} \pm 0.16$ & $7.88 \mathrm{~b} \pm 0.19$ & $7.50 \mathrm{~b} \pm 0.20$ & $6.97 \mathrm{a} \pm 0.11$ & $*$ \\
Neck (\%) & $7.43 \mathrm{a} \pm 0.16$ & $8.81 \mathrm{~b} \pm 0.15$ & $9.04 \mathrm{~b} \pm 0.12$ & $10.10 \mathrm{c} \pm 0.16$ & $*$ \\
Chest with fore thigh (\%) $^{19.73 \mathrm{c} \pm 0.42}$ & $18.82 \mathrm{~b} \pm 0.38$ & $17.94 \mathrm{a} \pm 0.36$ & $17.50 \mathrm{a} \pm 0.35$ & $*$ \\
Second thigh (\%) & $6.00 \pm 0.15$ & $5.90 \pm 0.12$ & $5.85 \pm 0.10$ & $5.98 \pm 0.09$ & $\mathrm{~ns}$ \\
By category (\%) & & & & \\
first & $33.89 \mathrm{a} \pm 0.85$ & $36.99 \mathrm{~b} \pm 0.74$ & $38.50 \mathrm{bc} \pm 0.69$ & $39.16 \mathrm{c} \pm 0.91$ & $*$ \\
second & $36.24 \pm 0.97$ & $36.13 \pm 0.72$ & $37.00 \pm 0.93$ & $35.45 \pm 0.83$ & $\mathrm{~ns}$ \\
third & $27.78 \pm 0.64$ & $23.56 \pm 0.88$ & $21.66 \pm 0.60$ & $20.31 \pm 0.79$ & $\mathrm{~ns}$ \\
\hline
\end{tabular}

Results are expressed as arithmetic mean and standard deviation.

a,b,c,d - means within rows bearing different letters are significantly different at $\mathrm{P} \leq 0.05$.

* $\mathrm{P} \leq 0.05$.

ns - non-significant.

${ }^{1}$ First $=$ leg + loin; Second $=$ shoulder + back + neck; Third $=$ chest with fore thigh + second thigh. 
Table 3. The proportion of muscle tissue, fat tissue (subcutaneous and intramuscular) and bones (\%) in four kid carcass side parts ${ }^{1}$

\begin{tabular}{l|r|r|r|c|c}
\hline $\begin{array}{c}\text { Carcass side } \\
\text { part }\end{array}$ & $\mathrm{B}$ & \multicolumn{1}{c}{$3 / 4 \mathrm{~B} 1 / 4 \mathrm{~S}$} & \multicolumn{1}{c}{$1 / 2 \mathrm{~B} 1 / 2 \mathrm{~S}$} & $1 / 4 \mathrm{~B} 3 / 4 \mathrm{~S}$ & $\mathrm{t}$-test \\
\hline $\begin{array}{c}\text { Leg } \\
\text { muscle }\end{array}$ & $68.57 \mathrm{a} \pm 1.47$ & $70.95 \mathrm{~b} \pm 1.52$ & $73.68 \mathrm{c} \pm 1.33$ & $74.91 \mathrm{c} \pm 1.84$ & $*$ \\
fat & $8.05 \pm 0.23$ & $8.91 \pm 0.36$ & $7.80 \pm 0.19$ & $8.13 \pm 0.41$ & $\mathrm{~ns}$ \\
$\quad$ bones & $22.53 \mathrm{~d} \pm 0.45$ & $20.43 \mathrm{c} \pm 0.47$ & $18.42 \mathrm{~b} \pm 0.51$ & $17.51 \mathrm{a} \pm 0.33$ & $*$ \\
Loin & & & & & \\
muscle & $70.88 \mathrm{a} \pm 1.38$ & $72.29 \mathrm{~b} \pm 1.52$ & $74.68 \mathrm{c} \pm 1.66$ & $75.66 \mathrm{c} \pm 1.77$ & $*$ \\
fat & $2.66 \pm 0.09$ & $2.78 \pm 0.10$ & $2.95 \pm 0.05$ & $2.77 \pm 0.08$ & $\mathrm{~ns}$ \\
bones & $26.13 \mathrm{c} \pm 0.59$ & $24.30 \mathrm{~b} \pm 0.56$ & $23.08 \mathrm{~b} \pm 0.37$ & $21.03 \mathrm{a} \pm 0.43$ & $*$ \\
Shoulder & & & & & \\
muscle & $69.56 \pm 1.52$ & $68.86 \pm 2.16$ & $71.80 \pm 1.73$ & $68.82 \pm 1.86$ & $\mathrm{~ns}$ \\
fat & $6.16 \mathrm{c} \pm 0.13$ & $6.54 \mathrm{~b} \pm 0.15$ & $5.22 \mathrm{ab} \pm 0.11$ & $4.71 \mathrm{a} \pm 0.11$ & $*$ \\
bones & $24.87 \pm 0.81$ & $23.63 \pm 0.53$ & $23.75 \pm 0.57$ & $24.90 \pm 0.76$ & $\mathrm{~ns}$ \\
Back & & & & & \\
muscle & $73.15 \pm 1.56$ & $72.88 \pm 2.02$ & $73.11 \pm 1.85$ & $72.93 \pm 2.09$ & $\mathrm{~ns}$ \\
fat & $3.53 \mathrm{c} \pm 0.09$ & $3.40 \mathrm{bc} \pm 0.09$ & $3.09 \mathrm{~b} \pm 0.10$ & $2.62 \mathrm{a} \pm 0.07$ & $*$ \\
bones & $23.47 \pm 0.62$ & $22.72 \pm 0.86$ & $23.84 \pm 0.37$ & $23.26 \pm 0.71$ & $\mathrm{~ns}$ \\
\hline
\end{tabular}

Results are expressed as arithmetic mean and standard deviation.

a,b,c,d - means within rows bearing different letters are significantly different at $\mathrm{P} \leq 0.05$.

* $\mathrm{P} \leq 0.05$.

ns - non-significant

${ }^{1}$ Dissection loss in the range from 0.1 to $1.0 \%$ is not presented in the Table.

Table 4. Chemical and technological characteristics of longissimus dorsi muscle in kids of different genotypes

\begin{tabular}{|c|c|c|c|c|c|}
\hline Parameters & B & $3 / 4 \mathrm{~B} 1 / 4 \mathrm{~S}$ & $1 / 2 \mathrm{~B} 1 / 2 \mathrm{~S}$ & $1 / 4 \mathrm{~B} 3 / 4 \mathrm{~S}$ & t-test \\
\hline Mass (g) & $164.27 \mathrm{a} \pm 3.69$ & $174.75 b \pm 4.72$ & $181.08 \mathrm{c} \pm 4.89$ & $193.85 \mathrm{~d} \pm 5.32$ & $*$ \\
\hline Length (cm) & $31.25 \pm 0.84$ & $32.67 \pm 0.61$ & $32.83 \pm 0.96$ & $33.25 \pm 1.04$ & ns \\
\hline $\mathrm{A}(\mathrm{cm})$ & $4.26 \pm 0.09$ & $4.42 \pm 0.12$ & $4.32 \pm 0.14$ & $4.16 \pm 0.13$ & ns \\
\hline $\mathrm{B}(\mathrm{cm})$ & $1.87 \mathrm{a} \pm 0.03$ & $1.97 \mathrm{ab} \pm 0.04$ & $2.05 \mathrm{ab} \pm 0.05$ & $2.18 \mathrm{~b} \pm 0.04$ & $*$ \\
\hline Rib eye area $\left(\mathrm{cm}^{2}\right)$ & $6.61 \mathrm{a} \pm 0.14$ & $6.81 \mathrm{ab} \pm 0.16$ & $7.05 \mathrm{bc} \pm 0.18$ & $7.17 \mathrm{c} \pm 0.17$ & $*$ \\
\hline \multicolumn{6}{|l|}{ Chemical composition } \\
\hline water $(\%)$ & $75.58 \pm 2.02$ & $75.55 \pm 1.58$ & $75.57 \pm 1.73$ & $76.17 \pm 1.78$ & ns \\
\hline fat $(\%)$ & $1.87 \mathrm{a} \pm 0.04$ & $1.97 \mathrm{a} \pm 0.04$ & $2.22 \mathrm{~b} \pm 0.03$ & $2.48 \mathrm{c} \pm 0.05$ & $*$ \\
\hline protein $(\%)$ & $21.46 \pm 0.68$ & $21.37 \pm 0.72$ & $21.10 \pm 0.66$ & $20.27 \pm 0.77$ & ns \\
\hline $\operatorname{ash}(\%)$ & $1.09 \pm 0.01$ & $1.11 \pm 0.02$ & $1.11 \pm 0.02$ & $1.08 \pm 0.02$ & ns \\
\hline water/protein & $3.47 \pm 0.12$ & $3.52 \pm 0.11$ & $3.54 \pm 0.12$ & $3.76 \pm 0.10$ & $\mathrm{~ns}$ \\
\hline collagen $(\%)$ & $0.34 \pm 0.01$ & $0.38 \pm 0.03$ & $0.37 \pm 0.01$ & $0.39 \pm 0.01$ & ns \\
\hline pigment content (ppm) & $85.92 \pm 3.17$ & $88.47 \pm 2.50$ & $89.75 \pm 4.21$ & $91.79 \pm 3.43$ & ns \\
\hline \multicolumn{6}{|l|}{ Technological properties } \\
\hline $\mathrm{pH} 24$ & $5.92 \pm 0.23$ & $5.62 \pm 0.18$ & $5.57 \pm 0.20$ & $5.61 \pm 0.17$ & ns \\
\hline $\mathrm{WBC}^{1}\left(\mathrm{~cm}^{2}\right)$ & $7.12 \mathrm{a} \pm 0.16$ & $7.49 \mathrm{ab} \pm 0.18$ & $7.67 b \pm 0.19$ & $8.18 \mathrm{c} \pm 0.22$ & $*$ \\
\hline shear force $\left(\mathrm{kg} / \mathrm{cm}^{2}\right)$ & $6.38 \mathrm{a} \pm 0.11$ & $6.86 \mathrm{ab} \pm 0.15$ & $7.47 b \pm 0.14$ & $7.25 \mathrm{~b} \pm 0.19$ & $*$ \\
\hline cooking loss $(\%)$ & $18.57 \pm 0.41$ & $19.11 \pm 0.47$ & $18.34 \pm 0.63$ & $20.35 \pm 0.53$ & ns \\
\hline
\end{tabular}

Results are expressed as arithmetic mean and standard deviation.

$\mathrm{a}, \mathrm{b}, \mathrm{c}, \mathrm{d}-$ means within rows bearing different letters are significantly different at $\mathrm{P} \leq 0.05$.

* $\mathrm{P} \leq 0.05$.

ns - non-significant.

${ }^{1} \mathrm{WBC}$ - water binding capacity. 
Table 5. Sensory evaluation of samples of longissimus dorsi muscle after roasting

\begin{tabular}{l|c|r|r|r|c}
\hline Sensory properties & \multicolumn{1}{c|}{$\mathrm{B}$} & \multicolumn{1}{c}{$3 / 4 \mathrm{~B} 1 / 4 \mathrm{~S}$} & \multicolumn{1}{c}{$1 / 2 \mathrm{~B} 1 / 2 \mathrm{~S}$} & \multicolumn{1}{c}{$1 / 4 \mathrm{~B} 3 / 4 \mathrm{~S}$} & $\mathrm{t}$-test \\
\hline Smell & $4.7 \pm 0.15$ & $4.1 \pm 0.12$ & $4.0 \pm 0.09$ & $4.1 \pm 0.16$ & $\mathrm{~ns}$ \\
Taste & $4.1 \pm 0.10$ & $4.2 \pm 0.07$ & $4.0 \pm 0.12$ & $4.2 \pm 0.11$ & $\mathrm{~ns}$ \\
Tenderness & $3.5 \mathrm{~b} \pm 0.07$ & $3.0 \mathrm{a} \pm 0.07$ & $3.6 \mathrm{~b} \pm 0.08$ & $3.9 \mathrm{~b} \pm 0.07$ & $*$ \\
Juiciness & $3.1 \mathrm{a} \pm 0.06$ & $3.3 \mathrm{ab} \pm 0.05$ & $3.8 \mathrm{~b} \pm 0.10$ & $3.9 \mathrm{~b} \pm 0.09$ & $*$ \\
\hline
\end{tabular}

Results are expressed in arithmetic mean and standard deviation.

$\mathrm{a}, \mathrm{b}, \mathrm{c}, \mathrm{d}-$ means within rows bearing different letters are significantly different at $\mathrm{P} \leq 0.05$.

$* \mathrm{P} \leq 0.05$.

ns - non-significant.

\section{Discussion}

Crossing of the Balkan autochthonous breed with the Saanen breed had an effect on changes in kid carcass traits (Table 1). The increase in the proportion of Saanen genes resulted in preslaughter weight being reached earlier at $18 \mathrm{~kg}$. The positive effect of crossing autochthonous and noble breeds on the kid body weight was reported also in other studies (Herold et al., 2007; Stanisz et al., 2009).

Van Niekerk and Casey (1988) report that significant differences between goat genotypes with regard to dressing percentage depend greatly on the weight of internal organs, offal and parts which are removed during slaughter. In this trial, the proportion of lungs, liver and small intestine increased with the increase in the proportion of Saanen genes $(\mathrm{P} \leq 0.05)$. However, the proportion of skin demonstrated an inverse trend and the highest value was established in purebred Balkan kids, which is probably the reason for absence of statistically significant difference in dressing percentage between the groups of kids.

It is known from literature data that thickness of subcutaneous fat tissue has a very considerable impact on chilling loss. This statement is confirmed by results obtained in this study, considering that kids with greater recorded thickness of subcutaneous fat tissue had lower chilling loss (Table 1). However, data in this study are not in concordance with the results of Tshabalala et al. (2003), Herold et al. (2007) and Stanisz et al. (2009) that crossing with noble breeds increases the proportion of fat tissue, considering that the maximum thickness of subcutaneous tissue was recorded in purebred Balkan kids and the lowest in kids with $75 \%$ of Saanen genes. Also, the proportion of total depot fat in carcass was the highest in kids from group B $(1.43 \%)$ and it decreased with the increase in the proportion of Saanen genes in the genotype.

Data presented in Table 2 are in concordance with the trial carried out by Stanisz et al. (2009) on Polish White kids and its crosses with Boer goat, where the proportion of leg in the carcass side increased with the increase in the proportion of Boer genes in the genotype and the highest value was determined in kids with $75 \%$ of Boer genes $(23.09 \%)$.

The increase in the proportion of Saanen genes contributed to the increase in the proportion of muscle tissue and the decrease in the proportion of bones in the leg and 
loin (Table 3). On the other hand, the proportion of fat tissue in shoulder and the back decreased and the lowest value was obtained for kids from group $1 / 4 \mathrm{~B} 3 / 4 \mathrm{~S}$. Stanisz et al. (2009) established that the proportion of muscle and fat tissues in kid carcass sides increased significantly, and the proportion of bones decreased with the increase in the proportion of Boer genes in the genotype. In this regard, in their research on the carcass composition of kids of different genotypes, Dhanda et al. (2003) stated that the proportion of muscle tissue of Saanen $\times$ Angora kids and Saanen $\times$ Feral kids was $69.0 \%$ and $69.8 \%$ in the leg, and $65.3 \%$ and $67.6 \%$ in the shoulder, respectively.

The use of noble breeds in crossing contributes to the increase in the proportion of fat in muscles (Brzostowski et al., 2008; Stanisz et al., 2009), which was confirmed in this study (Table 4).

The amount of collagen in kid meat (Table 4) showed no significant statistical difference between groups and was somewhat lower than the value reported by Wattanachant et al. (2008) for meat of kids of Anglonubian $\times$ Thai native and Saanen $\times$ Thai native breeds. Values of $\mathrm{pH}$ ranged from 5.5 to 5.9 (Table 4), which is considered as optimal $\mathrm{pH}$ value for high quality goat meat (Dhanda et al., 2003).

A higher proportion of intramuscular fat and hydrogen ions (lower $\mathrm{pH}$ value) can contribute to the decrease in the water binding capacity of meat (Oprządek and Oprządek, 2000). This claim was confirmed in the present study, considering that the water binding capacity in muscle samples from kids from group B (Table 4), which had the lowest value of intramuscular fat and the highest $\mathrm{pH}$ value, was the highest (7.12 $\mathrm{cm}^{2}$ of released juice).

The values of shear force showed a significant difference and ranged from $6.38 \mathrm{~kg} / \mathrm{cm}^{2}$ for meat of kids in group B to $7.47 \mathrm{~kg} / \mathrm{cm}^{2}$ for meat of kids in group $1 / 2 \mathrm{~B} 1 / 2 \mathrm{~S}$ (Table 4 ). These values were high compared to the results obtained by Dhanda et al. (1999). However, shear force values obtained in this trial were more favourable compared to those reported by Herold et al. (2007) and Shackelford et al. (1991).

Juiciness of meat is directly associated with the content of intramuscular fat, water and collagen, but water, which remains in the product after cooking has the greatest impact on juiciness during the consumption of meat (Webb et al., 2005). Scores for juiciness (Table 5) were higher for meat of kids in groups $3 / 4 \mathrm{~B} 1 / 4 \mathrm{~S}$ and $\mathrm{B}$ $(\mathrm{P} \leq 0.05)$, because they had more intramuscular fat.

Based on the data presented in this study it can be concluded that kids from group $1 / 2 \mathrm{~B} 1 / 2 \mathrm{~S}$ had better carcass quality parameters compared to kids from groups $\mathrm{B}$ and $3 / 4 \mathrm{~B} 1 / 4 \mathrm{~S}$, and better values of meat quality indicators compared to kids from group $1 / 4 \mathrm{~B} 3 / 4 \mathrm{~S}$. Improved autochthonous Balkan goat with $50 \%$ of Saanen genes could contribute to higher profitability in goat breeding, primarily because of the improvement of carcass conformation and increase in the amount of muscle tissue in the major carcass side parts.

\section{References}

AOAC (1990). Official methods of analysis. Washington, Association of Official Analytical Chemists. Brzostowski H., Niżnikowski R., Tański Z. (2008). Quality of goat meat from purebred French Alpine kids and Boer crossbreeds. Arch. Tierz., 51: 381-388. 
B unning K., Ham m R. (1970). Über die Haminbestimmung in Fleisch mittels der Methode von Horsney. Fleischwirtschaft, 50: 1541-1545.

Colomer-Rocher F., Kirton A.H., Mercer G.J.K., Duganzich D.M. (1992). Carcass composition of New Zealand Saanen goats slaughtered at different weights. Small Ruminant Res., 7: $161-173$.

De ve ndra C. (1982). Breed differences in productivity in goats. In: World Animal Science, Maijala K. (ed.). Disciplinary approach, B8. Elsevier, Amsterdam, The Netherlands, pp. 431-440.

Dh a n d a J.S., T a y lor D.G., M u r r a y P.J., M c k o s k e r J.E. (1999). The influence of goat genotype on the production of Capretto and Chevon carcasses. 2. Meat quality. Meat Sci., 52: 363-367.

Dhanda J.S., T a y 1 or D.G., Murray P.J. (2003). Part 1. Growth, carcass and meat quality parameters of male goats; effects of genotype and liveweight at slaughter. Small Ruminant Res., 50: 57-66.

G 1 i m p H.A. (1995). Meat goat production and marketing. J. Anim. Sci., 73: 291-295.

Gra u R., Ha m m R., B a u m a n n A. (1953). Über das Wasserbindungsvermögen des toten Säugetiermuskels. I. Mitteilung. Der Einfluß des pH Wertes auf die Wasserbindung von zerkleinertem Rindermuskel. Biochem. Z., 325: 1-11.

He rold P., S n e 11 H., T a w fik E.S. (2007). Growth, carcass and meat quality parameters of purebred and crossbred goat kids in extensive pasture. Arch. Tierz., 50: 186-196.

Oprządek J., Oprządek A. (2000). Factors affecting beef quality (in Polish). Prz. Hod., 8: $42-45$.

S h a c k e 1 ford S.D., M o r g a n J.B., C r o s s H.R., S a v e 11 J.W. (1991). Identification of threshold levels for Warner-Bratzler shear force in beef top loin steaks. J. Muscle Foods, 2: 289-296.

S t a n i s z M., Ś ló s a r z P., G u t A. (2009). Slaughter value and meat quality of goat kids with various share of Boer blood. Anim. Sci. Pap. Rep., 27: 189-197.

T s hab a la la P.A., S try d om P.E., W e b b E.C., d e K o c k H.L. (2003). Meat quality of designated South African indigenous goat and sheep breeds. Meat Sci., 65: 563-570.

Van N i e kerk W.A., C a s e y N.H. (1988). The Boer goat. II. Growth, nutrient requirements, carcass and meat quality. Small Ruminant Res., 1: 355-368.

Wattanachant S., Sornprasitt T., Polpara Y. (2008). Quality characteristics of raw and canned goat meat in water, brine, oil and Thai curry during storage. Songklanakarin J. Sci. Technol., 30: 41-50.

W ebb E.C., Cas ey N.H., Simela L. (2005). Goat meat quality. Small Ruminant Res., 60: 153-166.

W e n S.H., S u A.K., H s i e h R.C., Y a n S.S., W u J.S., C h a ng H.J. (1997). Breeding meat goats: upgrading Taiwan Native goats with Nubian goats. J. Taiwan Livest. Res., 30: 231-236.

Žu j o vi ć M., S t a n iš i ć N., M e m iš i N. (2009). Autochthonous Balkan goat breed - composition and traits of kid carcass. Biotechnol. Anim. Husb., 25: 411-420.

Accepted for printing 16 XI 2011

NIKOLA STANIŠIĆ, MIROSLAV ŽUJOVIĆ, ZORICA TOMIĆ, NEVENA MAKSIMOVIĆ, ZORICA BIJELIĆ, SNEŽANA IVANOVIĆ, NURGIN MEMIŠI

\section{Wpływ krzyżowania kóz rasy bałkańskiej i saaneńskiej na cechy tuszy i niektóre parametry jakości mięsa koźląt}

\section{STRESZCZENIE}

Badano możliwość poprawy cech tuszy i jakości mięsa koźląt autochtonicznej rasy bałkańskiej poprzez krzyżowanie z rasą saaneńską. Doświadczenie przeprowadzono na jednej grupie koźląt rasy bałkańskiej i trzech grupach koźląt pochodzących z krzyżowania kóz bałkańskich i saaneńskich 
o różnym udziale genów rasy saaneńskiej: 25, 50 i 75\%. W każdej z grup znajdowało się 16 samców koźląt, które ubijano przy średniej masie ciała wynoszącej $18 \mathrm{~kg}$. Wraz ze wzrostem udziału genów rasy saaneńskiej wiek koźląt, które osiągnęły przedubojową masę ciała, zmniejszał się, straty masy tuszki podczas schładzania rosły, a udział tkanki tłuszczowej (tłuszcz nerkowy i miednicowy) w półtuszy ulegał zmniejszeniu $(\mathrm{P} \leq 0,05)$. Krzyżowanie zwiększyło także udział części tuszy pierwszej kategorii (udziec i polędwica) oraz udział tkanki mięśniowej w tych wyrębach. Najwyższy udział tkanki mięśniowej w udzie $(74,91 \%)$ i polędwicy $(75,66 \%)$ stwierdzono u koźląt z grupy o $75 \%$ udziale genów rasy saaneńskiej. Koźlęta te charakteryzowały się także największym udziałem tłuszczu śródmięśniowego $(2,48 \%)$ w próbkach mięśnia najdłuższego grzbietu. Niewielkie różnice pomiędzy grupami koźląt wraz ze wzrostem udziału genów rasy saaneńskiej w genotypie, stwierdzono we właściwościach technologicznych mięsa, takich jak zdolność wiązania wody i kruchość. Mięso pieczone uzyskało wysoką ocenę sensoryczną, a ocena punktowa za kruchość i soczystość była nieznacznie wyższa u krzyżówek koźląt o 50 i 75\% udziale genów rasy saaneńskiej $(\mathrm{P} \leq 0,05)$. Wyniki uzyskane w tym doświadczeniu potwierdzają pozytywny wpływ krzyżowania rasy saaneńskiej z rasą bałkańską na cechy tuszy i uzyskanie mięsa o bardziej pożądanej jakości. 